\title{
Professional development in teacher digital competence and improving school quality from the teachers' perspective: a case study
}

\author{
Mercè Gisbert Cervera ${ }^{1 *}$, José L. Lázaro Cantabrana ${ }^{2}$ \\ 'Department of Pedagogy, School of Education Sciences, Rovira i Virgili University (URV), Spain \\ \{merce.gisbert@urv.cat\} \\ 2Department of Pedagogy, Faculty of Education Sciences, Rovira i Virgili University (URV), Spain \\ \{joseluis.lazaro@urv.cat\}
}

Received on 15 January 2015; revised on 20 January 2015; accepted on 13 March 2015; published on 15 July 2015

DOI: 10.7821/naer.2015.7.123

\begin{abstract}
Professional development in ICT for teachers, in addition to being necessary given the dynamic nature of technology, also improves the institutional quality of schools. This work, based on action research, provides evidence that the school itself is capable of organising and designing a training plan as part of a broader process to improve quality based on the incorporation of ICT. In turn, it addresses the pivotal elements of a training strategy that facilitates the transfer of that strategy to classroom activities and increases the quality of the school as an institution.
\end{abstract}

KEYWORDS: DIGITAL COMPETENCE FOR TEACHERS, TRAINING, QUALITY, SCHOOL

\section{INTRODUCTION}

Since the 1980s, the increasingly widespread use of technology in various areas of society has led to the emergence of the concept of an 'information society'. These new forms of accessing information have brought with them new ways of learning and generating knowledge, which in turn has led the previous concept to evolve into what is known as the 'knowledge society' (UNESCO, 2005).

The progressive 'digitalisation' of different areas of the knowledge society has modified and determined the way we live and how we interact, communicate, access our work, learn, and generate new knowledge (Brynjolfsson \& McAfee, 2014; European Union, 2013). As a result, today's citizens require a range of new knowledge and know-how in the form of skills which they must acquire and develop in order to effectively participate in modern society (Aguaded, 2012).

This situation raises the question of what new skills future citizens should possess and what skills teachers in charge of educating those citizens must also master.

In Catalonia, the context in which this work was carried out, the Government of Catalonia (2009) has adopted the term ‘digital competence' (DC) as a basic methodological skill which

\footnotetext{
*To whom correspondence should be addressed:

Facultat de Ciències de l’Educació, Universitat Rovira i Virgili (URV),

Carretera de Valls s/n, Campus Sescelades, 43005 Tarragona, Spain.
}

all students should possess by the end of compulsory education. Subsequently, the Government of Catalonia (2014) published guidelines for the development of basic digital skills based on certain international benchmarks, among which the National Educational Technology Standards for Students (ISTE, 2007) and Bloom's Taxonomy for the Digital Age (Churches, 2007) are particularly noteworthy.

For the sake of terminological clarification, we will briefly review what we mean by DC and our selected references. Gilster's work (1997) mentioned the concept of 'digital literacy' in relation to basic skills concerning the access, assessment, and management of information related to learning processes. Later on, Covello (2010) clarified the concept by defining seven characteristic components of digital literacy: identifying training needs, accessing information in digital environments, using ICT tools (educational and communications technologies) to manage information, interpreting and representing information, evaluating information, and transmitting information. In addition, Eshet-Alkalai (2012) considered digital literacy to be something that goes beyond the technical ability to use digital devices and which comprises a combination of a set of technical and procedural, cognitive, and socio-emotional skills which are necessary for living, learning, and working in a digital society.

Although internationally the concept of digital literacy (which is the more commonly used term) may appear as synonymous with DC, we feel that these two terms have different connotations. Larraz (2013) related the term DC to the sum of multiple literacies: technological, informational, audiovisual, and communicative. Ferrari, Punie, and Redecker (2012) interpreted DC as a new literacy involving new components and a high degree of complexity.

The context of this research is a public early childhood and primary school incorporating ICT in a variety of areas starting with the definition of quality indicators in each area. Training in digital competence for teachers (DCT) is one of the pivotal activities of the study, and in this article we shall discuss the planning, process, and results obtained in this area. The El Serrallo public school is located in the city of Tarragona and was found to be suitable for our particular research objectives and for improving the educational system in general. We detail below some of the school's characteristics: 
- Its structure serves as a model for other experiences because it covers a complete line of early childhood and primary education.

- It possesses a high level of 'maturity in the digital environment' in which the ICT used undergo regular study and innovation.

— The teaching staff is trained in educational technology, and the school has conducted eight ICT professional development sessions over the last 10 years.

— All of the instructors at the school are willing to take part in a research project.

As far as the context of this work is concerned, a chronological description of how the study was carried out is given below. Based on a comprehensive self-diagnosis of ICT incorporation, the school established quality indicators and performed analyses of training needs, considered to be an activity related to the established indicators. This systematic reflection on professional development and the self-assessment of learning needs are recognised as a basis for autonomous learning at the school level (Tejada, 2013). Using these two elements, a school training plan (STP) was developed, which was specified in the in-service training plan (ITP), constituting an ongoing professional development activity for the teaching staff.

Training activities for the teaching staff have to meet a number of conditions regulated by the educational administration for the purposes of recognition and certification. Certain aspects pertaining to the professional development of instructors have been included in various documents relating to regulations published by the Government of Catalonia (2009, 2013b and 2013c) as the educational administration. The following description refers to some of the aspects providing a framework for and justifying the training activities planned in this work.

In 2009, the administration was in charge of promoting training activities to be implemented at the workplace itself, such as those described in this study. In 2013, 'school success' was established as a priority objective of the educational system, and as such, various activities were proposed, such as the use of technology as a means of fostering improved teaching and learning processes, i.e. digital competence and professional development activity planning for the professional growth of teachers, while emphasizing the role of in-service training. At the same time, a series of priority guidelines were established for the professional development of the teaching staff. Among these, the most notable are those which make specific references and justify training in educational technology based on the following competences:

\section{— support for schools' educational projects}

— application of skill-based curricula

— development, monitoring, and evaluation of the digital competence of the student body as a general competence

- promotion of adequate attention to the diversity of the student body with specific needs in terms of educational support through digital inclusion

-improvement of the professional skills of instructors in their teaching practice: the digital competence of the teaching staff.

From this legal framework, the school then decided to design its ITP which is part of a 3-year STP, which, in turn, is part of the school educational project (SEP). The STP was prepared and approved by the teaching staff and then presented to the administration for initial approval leading to the possible certification of the activity.

\section{OBJECTIVES AND RESEARCH QUESTIONS}

The objectives of the work presented here are the result of a reflective process of institutional self-assessment, and are aimed at improving the school with regard to the incorporation of ICT and the training of instructors as key elements for improving quality.

\section{General objective:}

To develop a training plan for the school in order to improve the digital competence of the teaching staff based on quality indicators for the incorporation of ICT and an analysis of training needs.

\section{Specific objectives:}

- To design a professional development plan for the school to develop the digital competence of the teaching staff.

- To implement in-service professional development for the teaching staff in order to improve their digital competence (DC).

- To evaluate the school's professional development plan to improve the digital competence of the teaching staff.

\section{Research questions (RQ):}

RQ-1. Is it possible to relate the training needs of the teaching staff to the incorporation of ICT in the various areas of instruction?

RQ-2. Does providing training to improve the digital competence of the teaching staff have an impact on the teaching process?

RQ-3. Do teachers' perceptions of their own level of digital competence improve through in-service professional development?

\section{MATERIALS AND METHODS}

The work presented here consists of participatory action research (Kemmis and McTaggart, 1988), inasmuch as it comprises collective introspective enquiry undertaken by a participant (one of the teachers on the school's teaching staff) in order to improve and understand his/her own educational practice and the situations which may arise therein. With this type of research, the expected results include improving practice through change, improving the teaching staff through reflection on their practice, initiating processes of collaborative practice, systematizing learning and teaching processes, overcoming the resistance to change resulting from the research process, and recording the improvements made at the institution.

This work was conducted in keeping with the principles of qualitative research, as it responds to the following characteristics:

It is a small-scale study: it consists of an intensive examination of the case of an educational centre or other real and specific context (Bisquerra, 2000).

The researcher is part of the organisation under study, so the observations of the participant will be used when collecting 
and analysing the data in order to offer an interpretive understanding of the situation object of research.

Data triangulation is used, which involves cross-referencing the data obtained from various sources of information, with three different perspectives. (Carr and Kemmis, 1988).

The following instruments were employed for data collection:

Field diary: to gather the impressions and observations of the researcher during the process.

Observation log: external observations of the various training sessions.

Questionnaire: once completed, the training activity was assessed using a questionnaire from which qualitative data was obtained with regard to the following variables:

Personal and professional data:

- $\quad$ Initial training in ICT.

- $\quad$ The goals outlined for the training activity.

- Improvement of the DC og the teaching staff.

- Organisation of the activity.

- Methodology used.

- $\quad$ Future training activities.

Document analysis:

- Meeting records: stages, the ICT committee, staff meetings, etc.

- $\quad$ Records of training materials.

This work consisted of the following phases:

a) Diagnosis: theoretical documentation, analysis of the context and of training needs

b) Definition of objectives through reflection and needs analyses

c) Design and development of a training plan

d) Data collection and adaptation of the process

e) Evaluation

Reflection and formulation of proposals

The role of the researcher, as an instructor and part of the institution, was that of a participating observer who sought to provide an interpretive understanding of the situation in which the research was conducted. Simultaneously, this individual took on the role of facilitator and catalyst of change while striving to ensure the consistency and quality of the research process.

The teachers at the school were the key players, participating in order to improve their practice through processes of systematic reflection and action.

\section{RESULTS}

Before presenting the results, the personal and professional characteristics of the teaching staff involved in this research should be addressed:

The number of teachers who participated in the ITP was 22 (100\% of the faculty).

The majority of the teachers were female: 19 women and 3 men.

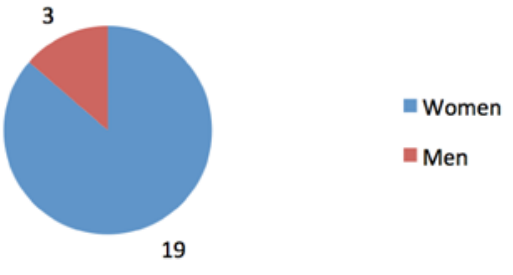

Figure 1. Teacher gender. Source: own development

Most of the teachers were between the ages of 36 and 45 . The number of teachers per age group was as follows: 2 between 26 and 35, 12 between 36 and 45, 7 between 46 and 55 , and 1 over 55 .
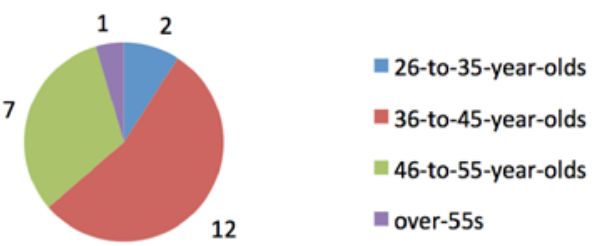

Figure 2. Teacher ages. Source: own development

The majority of the teachers had more than 13 years of professional experience. The breakdown of years of experience was: 1 teacher with 4 to 6 years of experience, 6 with 7 to 12 years, 9 with 13 to 20 years, and 6 teachers with more than 20 years of experience.

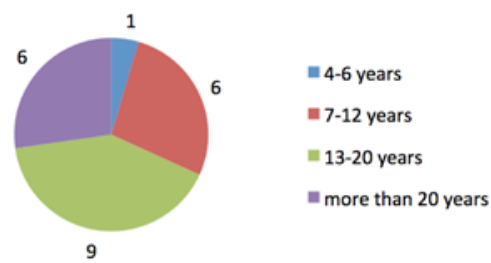

Figure 3. Figure 3. Teaching experience. Source: own development

The majority of the teachers were tutors for early childhood or primary education. The breakdown by teaching specialization at the school was: 4 teachers in early childhood education, 12 teachers in primary education, and 6 inter-level specialists.

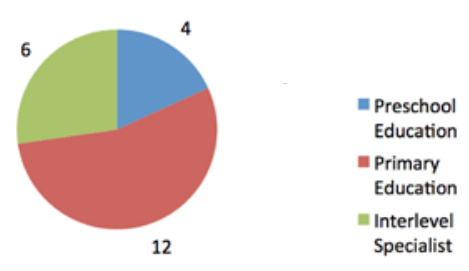

Figure 4. Teaching specialities. Source: own development

All of the teachers responsible for the management and organisation of the school participated in the training. The breakdown of management positions were: 3 teachers were part of the management team, and 5 were coordinators. 
ICT training: 10 teachers completed ICT training during their initial training and 12 did not. All of the instructors have undergone ICT professional development activities.

\subsection{Analysis of the context and of the training needs of the teaching staff}

Parallel to the ITP, a larger case study was conducted at the same institution. In the objectives of its ITP, the school takes into account institutional development in the areas analysed in the research and for which institutional quality indicators have been defined. Thus, the process followed by the school for the incorporation of technology has been planned in conjunction with research, which offers a greater degree of consistency and makes the process something that can be exported to other similar institutions. Early in the research, the research objectives and questions were established based on the areas in which ICT is incorporated in the school, as detailed below. From there, comprehensive quality indicators were established for the institution using self-analysis conducted by the teaching staff with regard to the incorporation of ICT (the school's 'TAC Plan'- technologies for learning and knowledge) (Government of Catalonia, 2015).

The three areas for which quality indicators were defined in connection with the ITP are:

\section{a) Scope: management and organisation of ICT}

Indicators:

- The use of school space is organised according to the use of ICT resources.

- There is a virtual teaching-learning environment (VTLE).

b) Scope: educational project and curriculum development Indicators:

- Training activities are conducted based on the analysis of training needs for the development of DC among the teaching staff.

- The ICT spaces are organised.

- DC work by the student body is present in the scheduling of different areas of the curriculum.

- A variety of teaching-learning activities (collaborative group projects, content generation, etc.) are used to practise instrumental skills, perform searches, analyse processes, and present information, among other things.

- The 'TAC programme’ (TAC: Technologies for Learning and

Knowledge) is in place and in use.

c) Scope: relationship with the surroundings

Indicators:

- Blogs, the internet, VTLE, etc. are used in teaching-learning activities.

In relation to these areas and depending on the defined quality indicators, a training strategy was designed to further their development by prioritizing the aspects deemed most pertinent by the teaching staff (through the formation of committees and working groups). This has proved a satisfactory method of organisation for sharing knowledge and commitment among equal stakeholders (Gairín and Rodríguez-Gómez, 2011), as well as for establishing training objectives based on the priorities defined and expressed by the teachers at the school.

The training needs analysis was performed on three levels:

f) Management team and ICT coordinator: As stipulated by the Government of Catalonia (2013a), the function of these individuals is to assess the teaching staff, plan and suggest training activities at the school, and to establish the STP. The necessary training priorities which had to be covered were established based on the educational track of the school, the needs arising from the implementation of curricula for the appropriate competences, and the school's quality indicators.

b) ICT committee: Comprised of the ICT coordinator, the coordinators of all the stages, and a member from the management team, it established the priorities to be pursued at the institutional level - expressed as objectives - in order to improve the quality of the school and to respond to classroom situations in which the use of ICT could be improved.

c) Individual: Each teacher expressed his/her particular training needs and priorities to the rest of the faculty.

Through this analysis it was concluded that the teachers should:

a) Understand the organisation of the skill-based school curriculum and, more specifically, the role of DC as methodological competence.

b) Contemplate, share, and design work strategies for DC in the classroom.

c) Be familiar with classroom resources for DC work.

These conclusions served as the starting point for designing the training activities at the school.

\subsection{Training design}

Professional development activities are commonplace in the dynamic of the school in which this work was conducted. In this regard, Russell, O’Dwyer, Bebell, and Tao (2007) highlight the need to take into account aspects related to the experience of the teachers at the school itself as a key component in defining professional development in ICT. The school has a high level of maturity in terms of the incorporation of ICT due to factors such as the following:

Because of its organisation and management of spaces and ICT resources, it is a centre of educational administration training which organises activities for other schools or groups of teachers.

It has extensive experience in organising in-service professional development in this area.

It participates in ICT innovation projects: internal and external (strategic plans for educational administration, innovation projects with the URV and a pilot centre which incorporates ICT resources experimentally).

It continuously reviews and updates the SEP in areas related to the use of technology.

The forecasted transfer or impact of the STP can be explained on the basis of three actions considered during the planning phase:

a) The ITP, which was designed from a needs analysis, makes it easier for the results obtained from this process to potentially have a high degree of impact on educational practices, both in the classroom and in the school as a whole.

b) The methodology behind the training activities, which is based on the work of collaborative groups that analyse, reflect upon, and design educational practice, facilitates 
easy access to the results by all of the members of the teaching staff.

c) One of the results of the training sessions was a curricular plan at the school level, including a DC component, which was accepted and approved by the teaching staff.

Through this analysis, as well as an assessment of the needs expressed and the administration's offer of training hours based on the school's proposal (40 hours in the context of 'in-service professional development'), the following objectives were defined:

\section{Objectives of the school's in-service training plan}

- To analyse the skills-based curriculum and the changes implied by this organisation with regard to digital competence.

- To identify and compile the objectives and the content of the various curricular areas which make specific reference to the DC of pupils.

- $\quad$ To design teaching-learning situations for content work involving the development of DC while taking into account the scenarios in which they are developed, ICT resources and ICT tools.

- To analyse the use and potential for blogs, websites, and a virtual teaching and learning environment at the school by proposing teaching-learning activities in which the educational community may participate.

Based on the content of this section, we can respond affirmatively to RQ-1. Is it possible to relate the training needs of the teaching staff to the incorporation of ICT in the various areas of instruction?

\subsection{Training assessment}

\section{Impact of the training}

The impact of the school's in-service training plan was measured based on the data obtained from three different sources:

a) The researcher, through notes made in his/her field diary.

The researcher noted in his/her diary - over the course of several training sessions and in particular the last - that there was evidence that several of the school's teachers had implemented DC programmes in the classroom through the implementation of activities planned by the working groups organised during the training.

The sessions in which any of the activities designed were carried out in the classroom were discussed during training sessions.

b) The outside observer, through the records kept during the three training activity sessions.

During the course of the last in-service training session, the various groups presented some of the activities implemented in the classroom which they had previously designed.

All of the groups presented the teaching activities supporting their presentations with instructional planning and graphic evidence recorded during their sessions.

c) The documents and programmes making up the professional development plan prepared during the activity.
All stages of primary education designed their curricular and instructional plans for the fundamental areas (Catalan, Spanish, and mathematics), as well as for knowledge of the social and natural environment. At the early childhood education level, curricular and instructional planning was done in the areas of self- and interpersonal discovery, discovery of the environment, and communication and languages.

The programmes were prepared according to the model agreed upon by the teaching staff and they contain all of the components which must be present in the stipulated document, including methodological guidelines (which should facilitate subsequent application in the classroom). These programmes were made available on the school's intranet.

Based on the evidence collected, it is possible to address the second research question: RQ-2. Does providing training to improve the digital competence of the teaching staff have an impact on the teaching process? We concluded that the inservice teacher training described here has had an impact on the activities of the teaching staff in the classroom because they have applied the designs created by the working teams while taking responsibility for their implementation in the classroom and adopting the methodologies agreed upon in the training sessions.

\section{Evaluation of training activities by the teaching staff}

The results yielded by means of analysing the answers to the questions posed in the questionnaire with regard to training activities related to teaching tasks include the following aspects:

Identification of the objectives and content of the different curricular areas related to DC work. 85\% of the teaching staff stated they were quite competent or very competent, while only $15 \%$ answered somewhat competent.

Design of teaching-learning activities and situations for the DC work. $79 \%$ of the teaching staff claimed to be quite competent or very competent, while only $21 \%$ answered somewhat competent.

Selection of adequate resources and tools for teachinglearning activities. $79 \%$ of the teaching staff said they were quite competent or very competent, while only $21 \%$ responded somewhat competent.

Sharing experiences and working collaboratively with other teachers at the school in relation to DC. $64 \%$ of the teaching staff answered that they were quite competent or very competent, while only $36 \%$ answered somewhat competent.

Application of new methodologies for DC work. 93\% of the teaching staff claimed to be quite competent or very competent, while only $7 \%$ responded somewhat competent.

To summarise, it should be noted that the area in which the teachers felt their competence improved the most was in the application of new methodologies. However, the area in which they report still having the most difficulties is in collaborative work.

Furthermore, in all of the tasks performed by the teachers during their training, their perception in terms of the development of competences was over $64 \%$ in all cases. 
As a final question in this set, the teachers were asked about their overall perception of the development of their own digital competence. 93\% felt that 'overall' their level of DC had improved significantly, while only $7 \%$ felt that it had only improved a little.

In this sense, an affirmative answer can be given to RQ-3: Do teachers' perceptions of their own level of digital competence improve through in-service professional development?

\section{DISCUSSION: PROFESSIONAL DEVELOPMENT IN DIGITAL COMPETENCE FOR TEACHERS}

From the initial concept of 'literacy', which is linked to the acquisition of reading, writing, and arithmetic, to its current meaning which necessarily includes the effective use of technology in different areas of personal and social development, the perspective offered by Larraz (2013) is particularly insightful. The author states that multiple areas of literacy cannot be separated from the social and educational needs to which the educational system must respond. Also of note is the approach described by Ferrari and colleagues (2012) in that DC clearly involves a high degree of complexity due to its dynamic nature, both for its various levels of development as well as its parameters in the form of indicators which define it and allow us to evaluate it.

In light of this, from a comprehensive focus on education as a tool for ensuring social cohesion, we feel that DC is a necessary element for individual development which the educational system should integrate in order to ensure participation in 21st century society (Martín \& Tyner, 2012; OCDE, 2011). For this to happen, teachers must be capable of training citizens who can use ICT as an inherent component in their personal and social development (European Commission, 2012, 2013 and 2014; OECD, 2012; Sánchez-Antolin, Ramos \& Sánchez Santamaría, 2014).

Based on this premise, it is necessary to design and develop training actions for teaching staff that address digital competence. We feel that these actions should be designed and developed to meet the institutional needs motivated by the responsibility of having to train future generations for a digital society.

From the perspective of the educational system, it is our position that training teachers to be able to take on the challenge of educating students who require continuously evolving skills is a justified investment (Cuban, 2001; UNESCO, 2004; Wilson, Grizzle, Tuazon, Akyempong \& Cheung, 2011), including in competences which traverse a variety of areas, like DC, as these ensure possession of a high level of adaptive capacity (Garcia \& Gairín, 2011).

From various reports and publications arising as a result of the massive incorporation of ICT in the field of education, the need for digitally competent teaching staff is obvious (Almås \& Krumsvik, 2007; European Commission, 2012, 2013 and 2014; UNESCO, 2008, 2011 and 2013). In every case, it is clear that teachers need a level of DC that will allow them to use technology effectively and appropriately, as well as a sufficient level of skill development suitable for their students and the learning needs thereof. This skill level of the teachers in the digital realm is what we define as their 'digital competence', with regard to which various international institutions have proposed ICT standards (EPICT, 2006; ISTE, 2008; UNESCO, 2008) which organise the DC of teachers in the form of the knowledge and skills that the teachers should master in a various areas. We agree with Krumsvick's approach (2009) which specifies that teacher DC consists of four components: basic digital skills (Bawden, 2008; Covello, 2010), instructional competence with ICT (Gisbert \& Esteve, 2011; Koehler \& Mishra, 2008), and learning and training strategies and digital development.

As the most recent contribution in the Spanish context, the Ministry of Education (2014) presented key competences for teachers of the 21st century, which include several digital skills: instrumental skills, teaching and research skills, organisational and communication skills, information search skills, and the preparation of materials.

In the process of professional development for teachers, we feel that approaches which are too focused on technical or instrumental aspects should be rejected in favour of training actions centred on the use of ICT at the educational level and for curricular development, while always remaining practiceoriented (Cabero, 2004; Cabero \& Llorente, 2008). Based on the work of Marqués (2008) and Valverde, Garrido, and Fernández (2013), we have concluded that the 'instrumental-didactic' training of the teaching staff and the generation of horizontal structures of shared leadership are essential to improving the attitude towards innovation with ICT.

In summary, and with regard to the different aspects of teacher DC which we have expounded on in this work, we believe the 'TPACK model' put forth by Koehler and Mishra (2008) clearly reflects the relationship that must be established between the major components of teacher DC. Following this model would make it possible to optimise processes of ICT integration into the classroom from a didactic perspective rather than from a technological one.

\section{CONCLUSIONS}

Our conclusions fall into two sections: the first concerns teacher perceptions on their training and the second on the quality of the school itself.

\section{Perception of the teaching staff with regard to improvements in their DC through professional development}

Teacher perceptions on how their level of digital competence has developed through the experiences they had was expressed in their assessment of the in-service professional development actions. Their sense of ability or self-efficiency determines how they handle the challenges of taking on new goals with new methodologies such as systematic work on the digital competence of students, which was one of the training objectives. Positive self-perception regarding the increase in their teaching ability is crucial for achieving the level of effort and perseverance required by this innovative activity (Bandura, 1986).

Upon completion of the training, a questionnaire verified the positive perception held by the teachers with regard to the development of their digital competence.

\section{Improving school quality in the incorporation of ICT}

Based on the quality indicators defined for the school and which pertain to in-service training, and using data collected during the research it can be concluded that:

a) In the area of 'ICT management and organisation': 
Spaces with ICT equipment in the school are identified and their use is taken into account in the programmes.

A virtual teaching and learning environment is used at the school as a space for communication and information, as a repository for teaching materials and as a virtual teachinglearning environment for the middle and upper school sections.

b) In the area of the 'educational programme and curricular development':

The ITP was developed based on a needs analysis.

The school's ICT spaces are organised.

Student digital competence focuses on four curricular areas in primary education (Catalan, Spanish, mathematics, and environmental knowledge), and on three areas of early childhood education, which have been analysed from a curricular perspective and on the basis of which the DC programme has been prepared.

Teachers conduct activities directed at developing student digital competence through teaching-learning activities.

The ICT-LCT programme of all the stages at the school is available to teachers on the school's intranet.

c) In the area of 'relationship with the surroundings':

Blogs are used in the early childhood education stages and in the initial primary education stage;

A virtual teaching and learning environment (Moodle) is used at the middle and upper stages of primary education.

In summary, we would like to highlight the following aspects relating to the improvement of the school:

The school has rendered the teaching-learning processes systematic through the implementation and development of the training programme in the digital arena (student DC). This fact, though not the result of a requirement by the educational administration but instead arising from a process of raising institutional awareness to improve quality, hints at a curricular development born from a process of professional contemplation of one's practice.

The institution has 'up-to-date' teachers who have participated in an in-service professional development process based on the implementation of innovative methodologies. The teachers have advanced in their personal development through ongoing training at the institution over the course of three years, paying attention to the training needs expressed by the school. Additionally, there is evidence of the transfer of training results in the development of the school's curricular project, classroom programmes, and teaching materials prepared collaboratively.

The school has developed its own SEP, achieving some of the objectives defined to improve institutional quality in different areas.

The school's culture of collaboration, based on the strategies used in in-service professional development, has generated internal work processes around which the training activities were organised.

\section{PROPOSALS}

\subsection{How the school can improve}

In light of the results obtained by analysing the areas of ICT incorporation and their quality indicators, the school should continue moving forward and formulating new objectives and indicators in order to continue its systematic collection of evidence to document changes and ensure quality.

As an inherent element for institutional improvement, the school should continue developing its professional development plan in ICT for the teaching staff, as outlined in its overall training plan.

\subsection{Professional development: the school training plan}

The school training plan encompasses three years of training from which we have collected data only from the first year. The training process must pass through three stages, of which two have already occurred ( $a$ and $b$ ):

a) Reflection: review of the curriculum (DC) and preparation of the professional development plan

b) Planning: analysis of tools, ICT resources, and the design of teaching-learning activities

Action: implementation of the curriculum by developing teaching units which involve DC work and the development of other teaching materials

The school's teaching staff, through responses to the questionnaire to assess the training action, has expressed its intention to continue receiving training in ICT at the school, thus furthering the training which has been implemented to date.

\section{REFERENCES}

Aguaded, J. L. (2012). Media proficiency, an educational initiative that cannot wait. Comunicar, 39, 07-08. doi:10.3916/C39-2012-01-01

Almås, A. G., \& Krumsvik, R. J. (2007). Digitally literate teachers in leading edge schools in norway. Journal of in-Service Education, 33(4), 479-497. doi:10.1080/13674580701687864

Bandura, A. (1986). Bases sociales de pensamiento y de acción: la teoría cognitiva social. Englewood Cliffs, NJ: Prentice-Hall.

Bawden, D. (2008). Origins and concepts of digital literacy. In Digital literacies: Concepts, policies and practices (pp. 17-32). New York: Peter Lang.

Bisquerra, R. (2000). Métodos de investigación educativa. Barcelona: CEAC S.A.

Brynjolfsson, E., \& McAfee, A. (2014). The Second Machine Age: Work, Progress, and Prosperity in a Time of Brilliant Technologies. New York: Norton \& Company.

Cabero, J. (2004). Formación del profesorado en TIC. El gran caballo de batalla. Comunicación y Pedagogía. Tecnologías y Recursos didácticos.

Cabero, J., \& Llorente, M. C. (2008). La Alfabetización Digital de los alumnos. Competencias Digitales para el siglo XXI. Revista Portuguesa de Pedagogía, 42(2), 7-28. doi:10.14195/1647-8614_42-2_1

Carr, W., \& Kemmis, S. (1988). Teoría crítica de la enseñanza: la investigaciónacción en la formación del profesorado. Barcelona: Martínez Roca.

Comisión Europea (2012). Informe conjunto de 2012 del Consejo y de la Comisión sobre la aplicación del marco estratégico para la cooperación europea en el ámbito de la educación y la formación (ET 2020). Retrieved from http://eur-lex.europa.eu/legalcontent/ES/TXT/PDF/?uri=CELEX:52012XG0308(01)\&from=ES

Comisión Europea (2013). Monitor Education and Training 2013. Retrieved from http://ec.europa.eu/education/library/publications/monitor13_en.pdf

Comisión Europea (2014). Monitor Education and Training 2014. Retrieved from http://ec.europa.eu/education/library/publications/monitor14 en.pdf

Covello, S. (2010). A review of Digital Literacy Assessment Instruments. IDE-712 Front-End Analysis Research. Analysis for Human Performance Technology Decisions. Syracuse University, School of Education. Retrieved from http://idmodule.com/research-on-digital-literacy-assessment-instrumentsfulltext/ 
Cuban, L. (2001). Oversold and underused: computers in the classroom. Cambridge, Mass.: Harvard University Press. doi:10.1080/14759390200200228

EPICT (2006). European Pedagogical ICT Licence: Concept description: EContent. Retrieved from http://www.epict.org/files/EPICTsyllabus.pdf

Ferrari, A., Punie, Y.,\& Redecker, C. (2012). Understanding digital competence in the 21st century: An analysis of current frameworks. In 21st century learning for 21st century skills (pp. 79-92). Springer. doi:10.1007/978-3-642-33263-0_7 Retrieved from http://link.springer.com/chapter/10.1007\%2F978-3-642-33263$0 \_7$

García, M. J., \& Gairín, J. (2011). Competencies: The current reality and perspectives in the Spanish context. A case study research. Perspectiva Educacional, $50(2)$.

Gairín, J., \& Rodríguez-Gómez, D. (2011). Cambio y mejora en las organizaciones educativas. Educar, 47(1), 31-50. doi:10.5565/rev/educar.70

Generalitat de Catalunya (2007a). Decret 142/2007, de 26 de juny, pel qual s'estableix l'ordenació dels ensenyaments de l'educació primària (Diari Oficial de la Generalitat de Catalunya, núm. 4915, 29/06/2007).

Generalitat de Catalunya (2007b). Decret 143/2007, de 26 de juny, pel qual s'estableix l'ordenació dels ensenyaments de l'educació secundària obligatòria (ESO) (Diari Oficial de la Generalitat de Catalunya, núm. 4915, 29/06/2007).

Generalitat de Catalunya (2009). Llei 12/2009. Llei d’Educació de Catalunya (Diari Oficial de la Generalitat de Catalunya, núm. 5422, 16/07/2009).

Generalitat de Catalunya (2013a). Documents per a l'organització i la gestió dels centres. Formació del personal dels centres educatius. Retrieved from http://educacio.gencat.cat/documents/IPCNormativa/DOIGC/GEST_Formacio PAS.pdf

Generalitat de Catalunya (2013b). Documents per a l'organització i la gestió dels centres. Objectius prioritaris del sistema educatiu i projecte educatiu de centre. Retrieved from

http://educacio.gencat.cat/documents/IPCNormativa/DOIGC/PEC_Objectius_P rojecte.pdf

Generalitat de Catalunya (2013c). Línies de formació 2013-2014. Línies aprovades pel Comitè de Formació del Departament d'Ensenyament en la sessió del dia 30 de març de 2012. Retrieved from http://www.xtec.cat/web/formacio/linies_formacio

Generalitat de Catalunya (2014). Competències bàsiques de l'àmbit digital. Retrieved from

http://www20.gencat.cat/docs/Educacio/Home/Departament/Publicacions/Col_ leccions/Competencies_basiques/competencies_digital_primaria.pdf

Generalitat de Catalunya (2015). Departament d'Ensenyament: El Pla TAC, un instrument per a la governança de les tecnologies al centre docent. Retrieved from http://www.xtec.cat/web/centres/projeducatiu/platac

Gilster, P. (1997). Digital Literacy. New York: Wiley and Computer Publishing.

Gisbert, M., \& Esteve, F. (2011). Digital Leaners: la competencia digital de los estudiantes universitarios. La Cuestión Universitaria, 7, 48-59.

ISTE (2007). Estándares nacionales (EEUU) de tecnologías de información y comunicación (TIC) para estudiantes. Retrieved from http://www.eduteka.org/pdfdir/EstandaresNETSEstudiantes2007.pdf

ISTE (2008). NETS·T for Teachers: National Educational Technology Standards for Teachers (Second Edition). EUA. Retrieved from http://www.eduteka.org/pdfdir/EstandaresNETSDocentes2008.pdf

Kemmis, S., \& McTaggart, R. (1988). Cómo planificar la investigación-acción. Madrid: Laertes.

Koehler, M. J., \& Mishra, P. (2008). Introducing tpck. In AACTE Committee on Innovation and Technology (Ed.), The handbook of technological pedagogical content knowledge (tpck) for educators (pp. 3-29). Mahwah, NJ: Lawrence Erlbaum Associates.

Krumsvik, R. J. (2009). Situated learning in the network society and the digitised school. European Journal of Teacher Education, 32(2), 167-185. doi:10.1080/02619760802457224

Larraz, V. (2013). La competència digital a la universitat (Doctoral dissertation, Universitat d'Andorra). Retrieved from http://hdl.handle.net/10803/113431

Martín, A. G., \& Tyner, K. (2012). Educación para los medios alfabetización mediática y competencia digital. Comunicar, 19, 31-39. doi:10.3916/C382012-02-03

Marqués, P. (2008). Las competencias digitales de los docentes. Retrieved from http://peremarques.pangea.org/competenciasdigitales.htm

Ministerio de Educación (2014). Competencias digitales del docente del S. XXI. Retrieved from

http://formacionprofesorado.educacion.es/index.php/es/competenciadigital/310-competencias-digitales-del-docente-del-siglo-xxi?showall=1 (consultado el 22/02/2014).

OCDE (2011). Informe habilidades y competencias del siglo XXI para los aprendices del nuevo milenio en los países de la OCDE. Retrieved from http://recursostic.educacion.es/blogs/europa/media/blogs/europa/informes/Habi lidades_y_competencias_siglo21_OCDE.pdf
OECD (2012). Education at a Glance 2012 (OECD indicators). doi:10.1787/eag2011-en Retrieved from OECD website: http://www.oecd.org/edu/EAG\%202012_e-book_EN_200912.pdf

OCDE (2014). Panorama de la educación. Indicadores de la OCDE 2014. Informe español. Retrieved from http://www.mecd.gob.es/dctm/inee/indicadoreseducativos/panorama2014/panorama-de-la-educacion-2014informe-espanol05-sep-.pdf?documentId=0901e72b81a722ac

Russell, M., O’Dwyer, L., Bebell, D., \& Tao, W. (2007). How Teachers' Uses of Technology Vary by Tenure and Longevity. Journal of Educational Computing Research, 37(4), 393-417. doi:10.2190/EC.37.4.d

Sánchez-Antolín, P., Ramos, F. J., \& Sánchez Santamaría, J. (2014). Formación continua y competencia digital docente: el caso de la Comunidad de Madrid. Revista Iberoamericana de Educación, 65, 91-110.

Tejada, J. (2013). Professionalisation of Teaching in Universities: Implications from a Training Perspective. RUSC. Universities and Knowledge Society Journal, 10(1), 345-358. doi:10.7238/rusc.v10i1.1471

UNESCO (2004). Las tecnologías de la información y la comunicación en la formación docente. Guía de planificación. París: División de Educación Superior. UNESCO.

UNESCO (2005). Hacia las sociedades del conocimiento. Retrieved from http://portal.unesco.org/culture/es/ev.phpURL_ID=29619\&URL_DO=DO_TOPIC\&URL_SECTION=201.html

UNESCO (2008). Estándares de competencia en TIC para docentes. Retrieved from http://www.eduteka.org/modulos/11/342/868/1

UNESCO (2009). Directrices sobre políticas de inclusión en la educación. Retrieved from http://unesdoc.unesco.org/images/0017/001778/177849s.pdf

UNESCO (2011). Enfoques estratégicos sobre las TICs en educación en América Latina y el Caribe. Retrieved from http://unesdoc.unesco.org/images/0022/002232/223251s.pdf

UNESCO 2013. Enseñanza y aprendizaje: Lograr la calidad para todos (Report 2013/4). Retrieved from http://unesdoc.unesco.org/images/0022/002261/226159s.pdf

Unión Europea (2013). Comprender las políticas de la Unión Europea: Una nueva revolución industrial. Retrieved from http://europa.eu/pol/pdf/flipbook/es/enterprise_es.pdf

Valverde, J., Garrido, M. C., \& Fernández, M. R. (2013). La planificación de las políticas sobre tecnología educativa en el contexto del centro escolar el proyecto TIC. En M. Area Moreira (Ed.), Políticas educativas y buenas prácticas TIC. II Simposio internacional SITIC (pp. 133-142). Tenerife: Laboratorio de Educación y Nuevas Tecnologías de la Universidad de la Laguna (EDULLAB). Retrieved from http://edullab.webs.ull.es/wordpress/wp-content/uploads/2013/12/ACTASSITIC-TENERIFE-2013.pdf

Wilson, C., Grizzle, A., Tuazon, R., Akyempong, K. \& Cheung, C. (2011). Alfabetización mediática e informacional. Currículum para profesores. París: UNESCO. Retrieved from http://unesdoc.unesco.org/images/0021/002160/216099S.pdf 